\title{
Feeding of Calanus finmarchicus nauplii in the Irminger Sea
}

\author{
Xabier Irigoien ${ }^{1, *}$, Josefin Titelman ${ }^{2,4}$, Roger P. Harris ${ }^{2}$, Derek Harbour ${ }^{2}$, \\ Claudia Castellani ${ }^{3,5}$
}

\author{
${ }^{1}$ AZTI (Fisheries and Food Technological Institute), Herrera Kaia Portualdea, 20110 Pasaia, Spain \\ ${ }^{2}$ Plymouth Marine Laboratory, Prospect Place, Plymouth PL1 3DH, UK \\ ${ }^{3}$ Southampton Oceanography Centre, European Way, Southampton SO14 3ZH, UK
}

${ }^{4}$ Present address: Department of Fisheries and Marine Biology, University of Bergen, Bergen 7800, 5020 Norway

${ }^{5}$ Present address: Plymouth Marine Laboratory, Prospect Place, Plymouth PL1 3DH, UK

\begin{abstract}
Recent studies have shown that the passage from nauplius to copepodite is a key event in the population dynamics of Calanus finmarchicus. As a first step towards understanding if and how trophic interactions influence this event, we investigated the feeding of $C$. finmarchicus nauplii IV-VI in the Irminger Sea during spring and summer in a series of incubation experiments. Generally, feeding efficiencies were highest on large cells, whereas small flagellates were ingested at very low rates. Colonies of Phaeocystis sp. were not ingested. Among the larger cells, the diatoms Chaetoceros pelagicus and Tropodineis sp. and the ciliate Strombidium sp. were the main food sources. We observed a negative relationship between the percentage of diatoms in the food environment and the filtration rate on Strombidium sp. We therefore suggest that the combination of low feeding efficiency on small cells and the generally low concentrations of ciliates in oceanic waters explains why $C$. finmarchicus relies on phytoplankton blooms for recruitment from nauplius to the first copepodite stage.
\end{abstract}

KEY WORDS: Calanus finmarchicus nauplii $\cdot$ Feeding $\cdot$ Phytoplankton $\cdot$ Microzooplankton

\section{INTRODUCTION}

The copepod Calanus finmarchicus is a key species in the North Atlantic, often representing over $50 \%$ of the zooplankton biomass (Planque \& Batten 2000). Due to their abundance, Calanus nauplii are a main food source for larvae of commercially important fish, i.e. cod, and of importance for their recruitment. The Irminger Sea between Iceland and Greenland is one of the major centres of $C$. finmarchicus distribution in the North Atlantic (Planque \& Batten 2000).

Calanus finmarchicus overwinters at depth, and it is generally assumed that after returning to the surface in spring, it exploits the phytoplankton bloom for reproduction. This view has recently been challenged by studies in the Norwegian Sea showing that by using its lipid storage, C. finmarchicus is able to produce eggs before the bloom, when food concentration is still low
(Irigoien et al. 1998, Niehoff et al. 1999). However, a detailed analysis of the population structure during the same study in the Norwegian Sea showed that although eggs are produced before the bloom, the resulting nauplii only recruit to copepodites when coincident with the bloom (Hirche et al. 2001) and that before the bloom the death rate is higher than the birth rate (Ohman \& Hirche 2001). These results suggest that the passage from nauplius to copepodite is a key event in the population dynamics of $C$. finmarchicus, and suggest that the phytoplankton bloom plays an important role in the success of naupliar development.

Unfortunately, our knowledge about Calanus nauplii feeding ecology is limited (Harris 1996). Only a few studies have examined their feeding and growth rates in the laboratory (Marshall \& Orr 1956, Paffenhofer 1971, Fernandez 1979, Rey et al. 2001, Meyer-Harms et al. 2002) and survival in response to starvation (Lopez 1996). To 


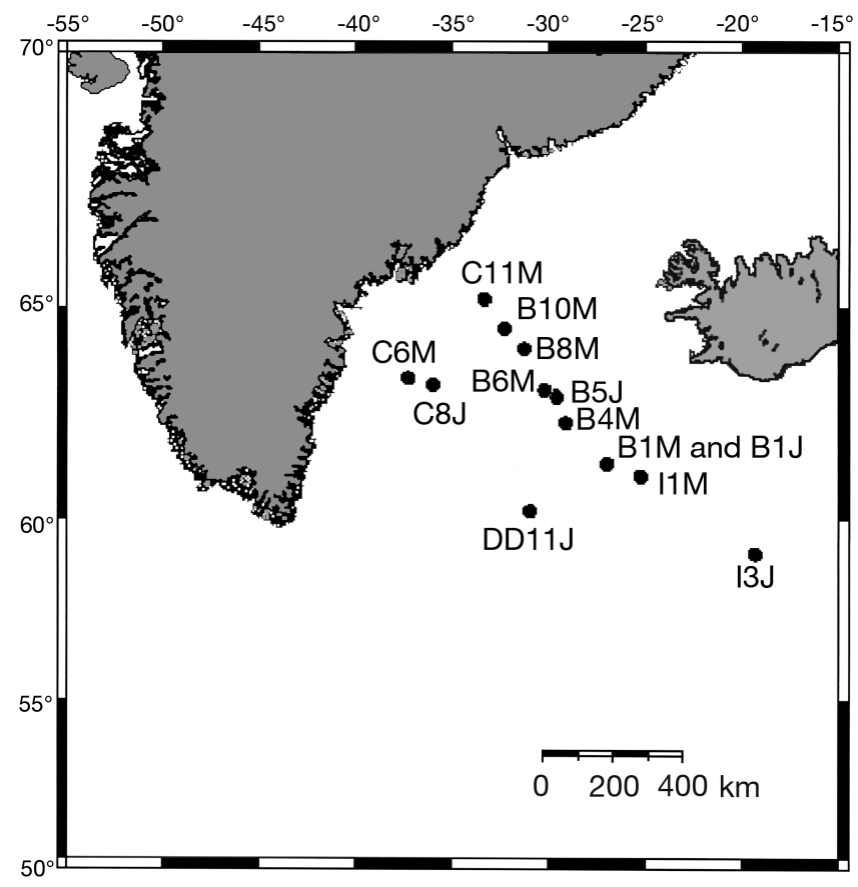

Fig. 1. Map of the study area our knowledge only 1 article on feeding of Calanus nauplii under natural conditions has been published (Turner et al. 2001). In the present study, we examined C. finmarchicus naupliar feeding on natural particles for a wide range of food conditions in the Irminger Sea.

\section{MATERIALS AND METHODS}

We quantified feeding rates and selectivity of Calanus finmarchicus nauplii in a series of shipboard experiments carried out during RRS 'Discovery' Cruises D262 and D264 in spring and summer 2002 in the Irminger Sea. Experimental stations are presented in Fig. 1 and basic parameters for each station can be found in Table 1.

Naupliar feeding rates on the different nano- and microplanktonic groups (cells $>2 \mu \mathrm{m}$ ) were quantified by incubating 15 to 25 Calanus finmarchicus nauplii, Stage IV to VI (mainly Stage V), in $200 \mathrm{ml}$ bottles filled with water from the chl a maximum. Nauplii were sorted from vertical hauls at all stations. In each experiment, 3 replicate experimental and 3 replicate control bottles were in-

Table 1. Position and main characteristics of the experimental stations. SST: sea surface temperature

\begin{tabular}{|c|c|c|c|c|c|c|c|}
\hline Stn & $\begin{array}{c}\text { Date } \\
\text { (d/mo/yr) }\end{array}$ & Position & $\begin{array}{l}\mathrm{SST} \\
\left({ }^{\circ} \mathrm{C}\right)\end{array}$ & $\begin{array}{l}\text { Surface } \\
\text { salinity }\end{array}$ & $\begin{array}{l}\text { Surface chl a } \\
\qquad(2 \mathrm{~m}) \\
\left(\mathrm{mg} \mathrm{m}^{-3}\right)\end{array}$ & $\begin{array}{l}\text { Experiment initial } \\
\text { nano- and micro- } \\
\text { plankton }\left(\mathrm{mg} \mathrm{C} \mathrm{m}^{-3}\right)\end{array}$ & Region (observations) \\
\hline \multicolumn{8}{|c|}{ Spring cruise } \\
\hline $\mathrm{I} 1 \mathrm{M}$ & $22 / 05 / 02$ & $\begin{array}{l}61^{\circ} 08^{\prime} 95^{\prime \prime} \mathrm{N} \\
25^{\circ} 26^{\prime} 04^{\prime \prime} \mathrm{W}\end{array}$ & 7.9 & 35.1 & 1.4 & 49 & Iceland Basin \\
\hline $\mathrm{B} 1 \mathrm{M}$ & $21 / 05 / 02$ & $\begin{array}{l}61^{\circ} 40^{\prime} 70^{\prime \prime} \mathrm{N} \\
27^{\circ} 02^{\prime} 46^{\prime \prime} \mathrm{W}\end{array}$ & 7.0 & 35.1 & 0.9 & 64.9 & Reykjanes Ridge \\
\hline B4M & $20 / 05 / 02$ & $\begin{array}{l}62^{\circ} 38^{\prime} 60^{\prime \prime} \mathrm{N} \\
29^{\circ} 14^{\prime} 60^{\prime \prime} \mathrm{W}\end{array}$ & 6.8 & 35.1 & 0.9 & 41.4 & Irminger Basin \\
\hline B6M & $19 / 05 / 02$ & $\begin{array}{l}63^{\circ} 17^{\prime} 09^{\prime \prime} \mathrm{N} \\
30^{\circ} 23^{\prime} 82^{\prime \prime} \mathrm{W}\end{array}$ & 7.1 & 35.1 & 0.8 & 27.6 & Irminger Basin \\
\hline B8M & $18 / 05 / 02$ & $\begin{array}{l}64^{\circ} 10^{\prime} 52^{\prime \prime} \mathrm{N} \\
31^{\circ} 29^{\prime} 32^{\prime \prime} \mathrm{W}\end{array}$ & 6.9 & 35.1 & 0.6 & 41.9 & Irminger Basin \\
\hline B10M & $17 / 05 / 02$ & $\begin{array}{l}64^{\circ} 56^{\prime} 97^{\prime \prime} \mathrm{N} \\
32^{\circ} 30^{\prime} 22^{\prime \prime} \mathrm{W}\end{array}$ & 5.6 & 34.7 & 1.4 & 32.3 & Irminger Basin \\
\hline $\mathrm{C} 11 \mathrm{M}$ & $16 / 05 / 02$ & $\begin{array}{l}65^{\circ} 20^{\prime} 16^{\prime \prime} \mathrm{N} \\
33^{\circ} 36^{\prime} 24^{\prime \prime} \mathrm{W}\end{array}$ & 7.9 & 35.2 & 1.1 & 92.3 & Greenland shelfbreak \\
\hline C6M & $11 / 05 / 02$ & $\begin{array}{l}66^{\circ} 44^{\prime} 38^{\prime \prime} \mathrm{N} \\
37^{\circ} 29^{\prime} 36^{\prime \prime} \mathrm{W}\end{array}$ & 1.2 & 33.3 & 1.2 & 212 & $\begin{array}{l}\text { Greenland shelf } \\
\text { (Partially ice covered; } \\
\text { fresh water in surface) }\end{array}$ \\
\hline \multicolumn{8}{|c|}{ Summer cruise } \\
\hline I3J & $30 / 07 / 02$ & $\begin{array}{l}59^{\circ} 12^{\prime} 57^{\prime \prime} \mathrm{N} \\
19^{\circ} 37^{\prime} 38^{\prime \prime} \mathrm{W}\end{array}$ & 11.6 & 35.2 & 0.9 & 38 & Iceland Basin \\
\hline DD11J & 04/08/02 & $\begin{array}{l}60^{\circ} 21^{\prime} 10^{\prime \prime} \mathrm{N} \\
31^{\circ} 00^{\prime} 26^{\prime \prime} \mathrm{W}\end{array}$ & 11.1 & 35.0 & 0.8 & 47.4 & Reykjanes Ridge \\
\hline B1J & $31 / 07 / 02$ & $\begin{array}{l}61^{\circ} 40^{\prime} 45^{\prime \prime} \mathrm{N} \\
27^{\circ} 00^{\prime} 52^{\prime \prime} \mathrm{W}\end{array}$ & 10.9 & 35.0 & 1.0 & 33.3 & Irminger Basin \\
\hline B5J & 02/08/02 & $\begin{array}{l}63^{\circ} 00^{\prime} 54^{\prime \prime} \mathrm{N} \\
29^{\circ} 59^{\prime} 32^{\prime \prime} \mathrm{W}\end{array}$ & 10.2 & 34.9 & 0.5 & 56 & Irminger Basin \\
\hline $\mathrm{C} 8 \mathrm{~J}$ & $10 / 08 / 02$ & $\begin{array}{l}63^{\circ} 29^{\prime} 51^{\prime \prime} \mathrm{N} \\
36^{\circ} 02^{\prime} 24^{\prime \prime} \mathrm{W}\end{array}$ & 9.9 & 35.0 & 1.2 & 67.4 & Greenland shelfbreak \\
\hline
\end{tabular}



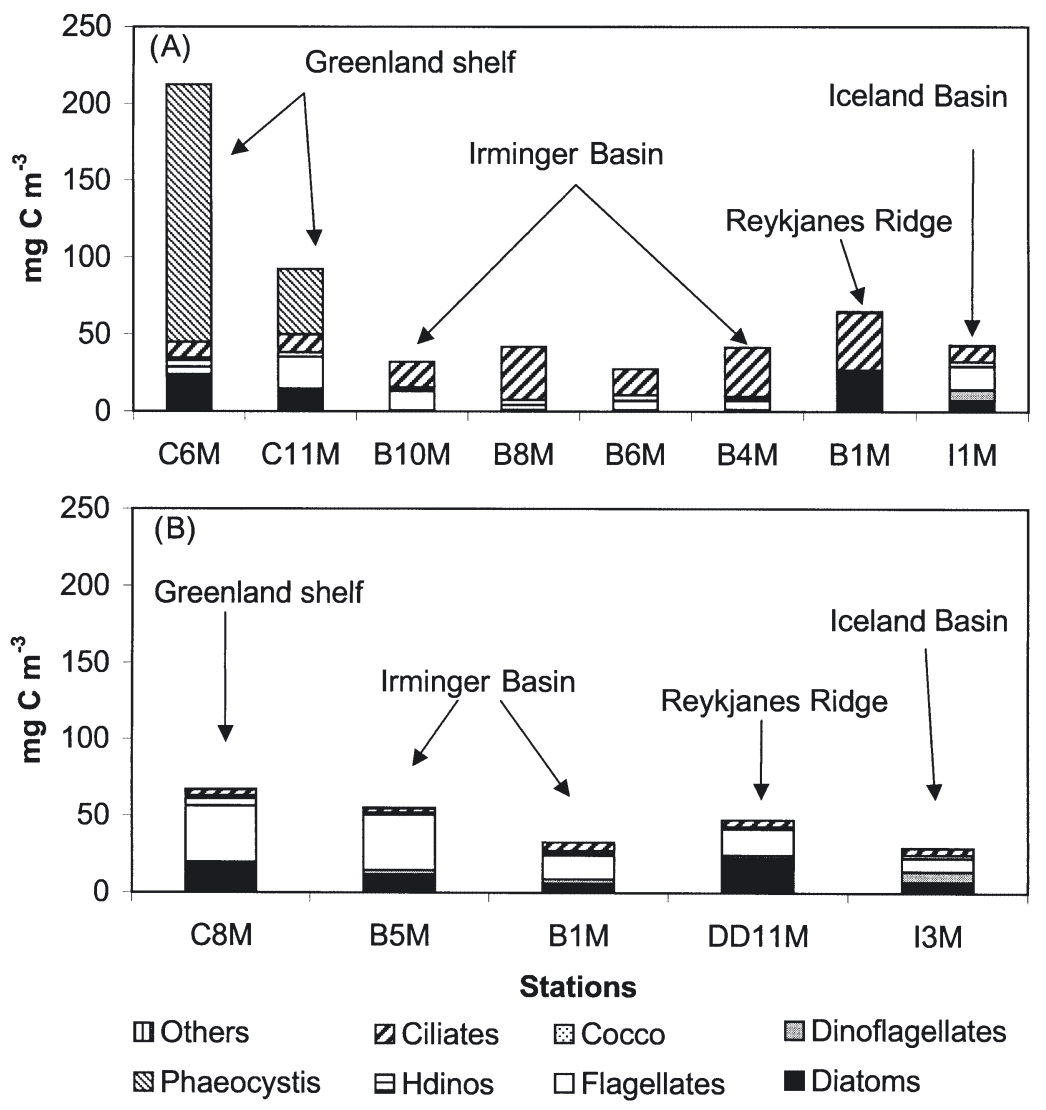

Fig. 2. Initial nano- and microplankton concentrations and composition at the different experimental stations. (A) Spring (B) summer
Frost (1972) for the taxa where there was a significant difference in concentration between controls and incubation bottles.

Food selection on specific phytoplankton groups was quantified using the selectivity index (SI) proposed by Chesson (1978). This index varies between 0 and 1 with $\mathrm{SI}_{i}$ $=0.5$ indicating non-selective feeding towards the prey $i, \mathrm{SI}_{i}>0.5$ indicates a preference for the prey $\mathrm{i}$ and $\mathrm{SI}_{i}<0.5$ indicates discrimination against the prey $i$.

\section{RESULTS \\ Food field}

Given the wide spatial and temporal coverage of this study (Fig. 1), we carried out experiments for a wide range of naturally occurring food conditions (Fig. 2a,b). In spring, the composition of nano- and microplankton differed significantly between stations (Fig. 2a). The Greenland shelf was characterized by a Phaeocystis sp. bloom reaching up to $212 \mathrm{mg} \mathrm{C} \mathrm{m}^{-3}$. In the Irminger Basin ciliates of the Strombidium type (20 to 30 ) dominated the biomass. In the Reykjanes Ridge region, the biomass was distributed almost equally between Strombidium and diatoms (mainly Chaetoceros pelagicus). Finally, in the Iceland

cubated on a plankton wheel $(0.1 \mathrm{rpm})$ for $\sim 24 \mathrm{~h}$ at sea surface temperature. A further bottle was filled and immediately fixed with acidic Lugol to estimate the food concentration at Time 0 . Experiments were terminated by adding acidic Lugol to the bottles (1\% final concentration, Holligan \& Harbour 1977).

A subsample of $100 \mathrm{ml}(1 / 2$ the incubation volume) was settled (Utermöhl 1958) and counted under an inverted microscope following Båmstedt et al. (2000). Heterotrophic dinoflagellates were separated from autotrophic forms according to Lessard \& Swift (1986) and Burkill et al. (1993). Phytoplankton carbon biomass was estimated from cell volume (Strathmann 1967) and using a factor of $0.21 \mathrm{pgC} \mathrm{\mu m}^{-3}$ (Ohman \& Runge 1994) for ciliates. No correction was applied for ciliate losses and cell shrinkage. Filtration and ingestion rates were calculated from the carbon concentrations following

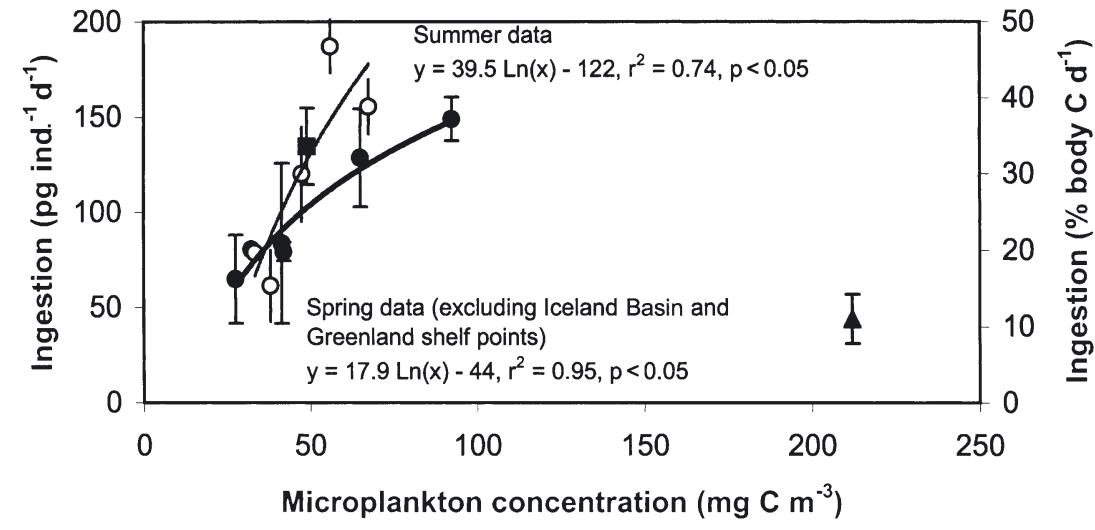

Fig. 3. Ingestion rates expressed as pg C ind.$^{-1} \mathrm{~d}^{-1}$ (left axis) and as \% body $\mathrm{C} \mathrm{d}^{-1}$ (right axis) as a function of nano- and microplankton carbon concentration. We assumed an average body weight of $0.4 \mu \mathrm{g} \mathrm{C}$ ind. ${ }^{-1}$ in calculations (Turner et al. 2001). (•) Spring data; (O) summer data. (A) Stn C6M (dominated by Phaeocys-

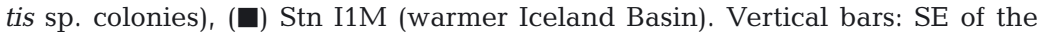
average for the ingestion expressed as $\mathrm{pg} \mathrm{C}$ ind..$^{-1} \mathrm{~d}^{-1}$ 
dinoflagellates (Dinophysis acuminata, Gyrodinium britannicum), and small flagellates (2 to $5 \mu \mathrm{m}$ ).

In summer, the biomass on the Greenland shelf was lower (67 $\mathrm{mg} \mathrm{C} \mathrm{m}^{-3}$ ) and dominated by small flagellates. Small flagellates also dominated in the Irminger Basin. In the Reykjanes Ridge region, the main components were small flagellates and diatoms (Tropodineis sp.). Again, the biomass in the Iceland Basin was distributed between diatoms Tropodineis sp., dinoflagel- lates Ceratium tripos, Protoperidinium depressum, small flagellates and ciliates Strombidium sp. (Fig. 2b).

\section{Feeding}

Ingestion ranged from 0.044 to $0.135 \mu \mathrm{g} \mathrm{C}$ ind. ${ }^{-1} \mathrm{~d}^{-1}$ in spring, and from 0.062 to $0.187 \mu \mathrm{g} \mathrm{C}$ ind..$^{-1} \mathrm{~d}^{-1}$ in summer (Fig. 3). Feeding rates were generally related
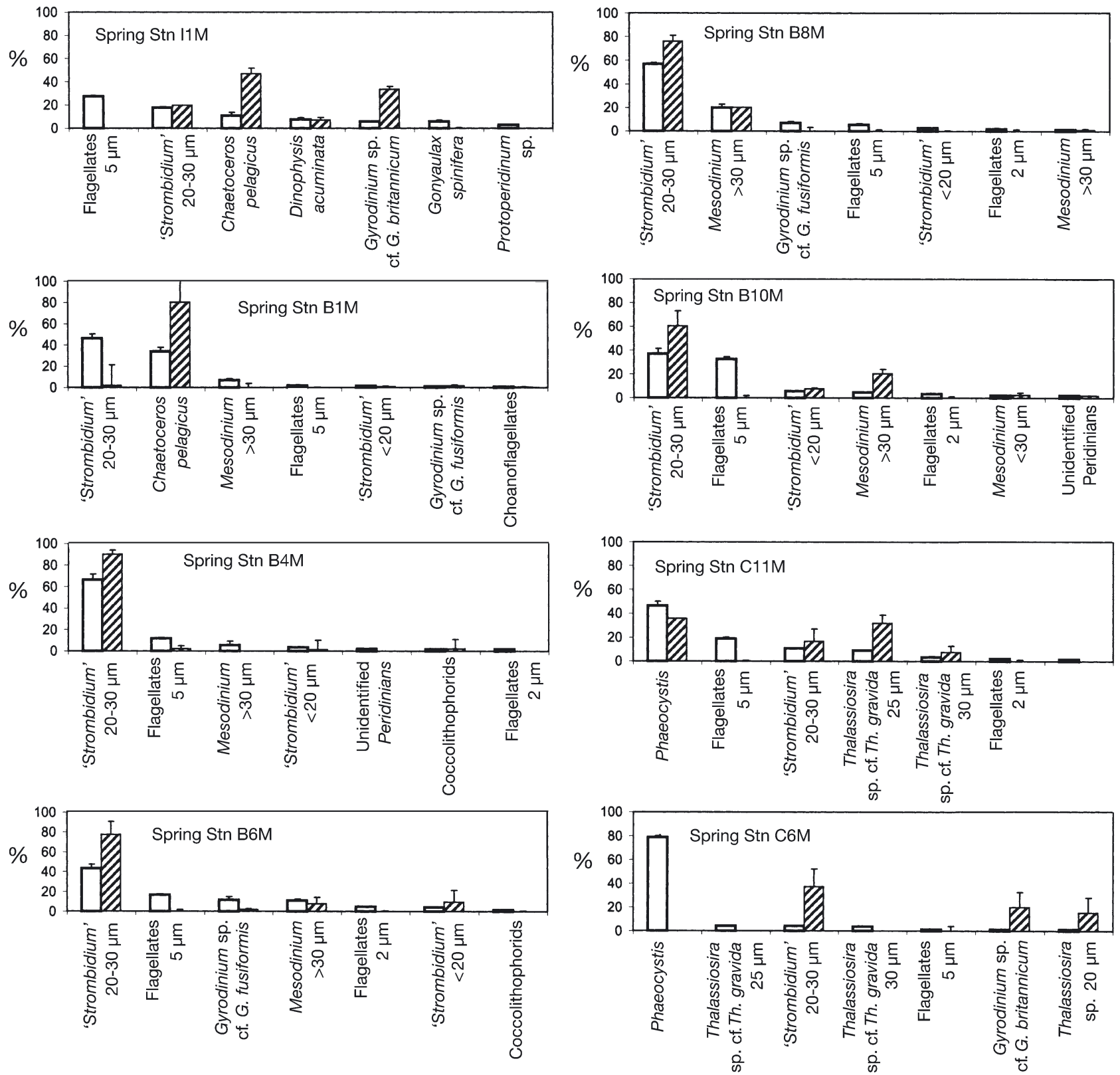

\% Microplankton C

WA Diet C

Fig. 4. (Above and next page) Percentage contribution of different types of cells to the nano- and microplankton and to the diet of Calanus finmarchicus nauplii at the different stations. Vertical bars: SE of the average 

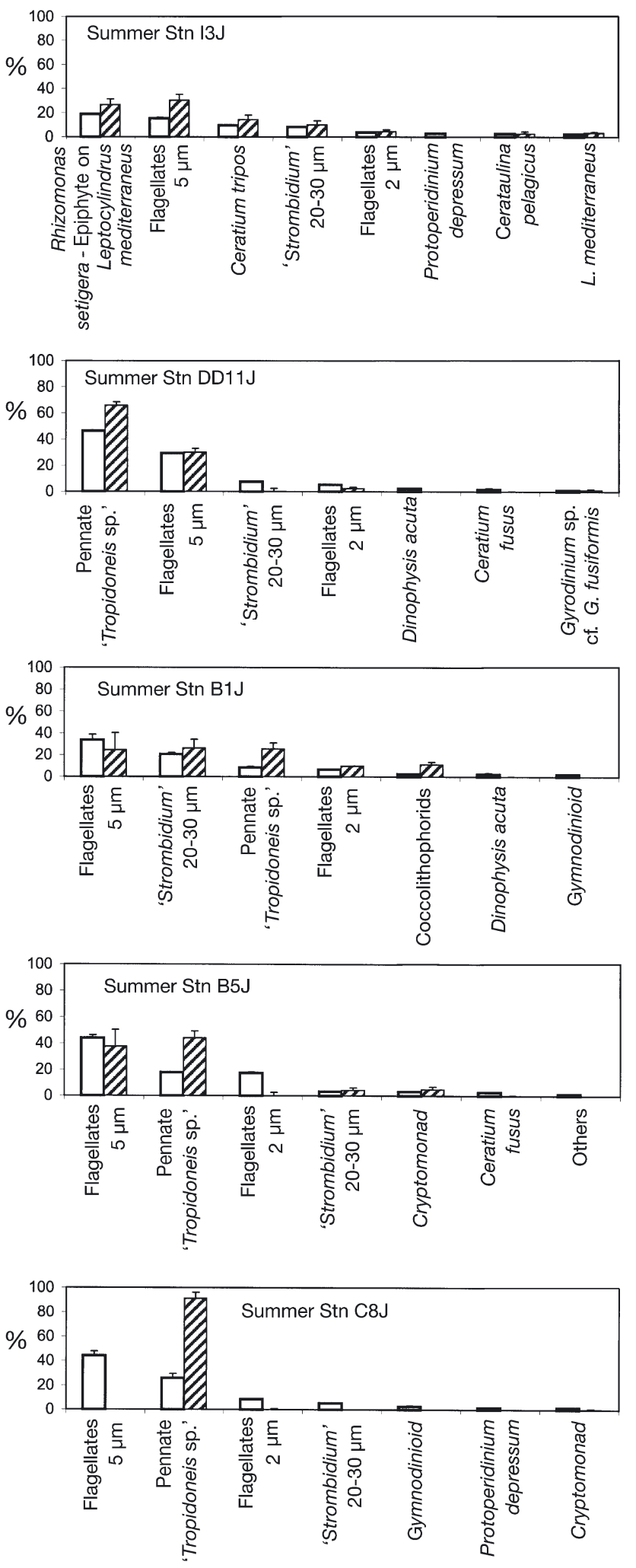

\% Microplankton C VA \% Diet C

Fig. 4. (continued) to the food concentration, except for the experiment with the Phaeocystis sp. bloom water (Stn C6M, Fig. 3). In the latter experiment, ingestion rates were much lower than that expected from the general relation between ingestion and food concentration (Fig. 3).

Interestingly, at Stn I3 in summer, a large fraction of the biomass was due to an epiphyte Rhizomonas setigera on the diatom Leptocylindrus mediterraneus. Although this epiphyte was important in the diet (Fig. 4), its capture has to be associated with that of the diatom.

\section{Clearance rates and selectivity}

The Calanus finmarchicus nauplii showed size selection, with no detectable ingestion of small flagellates during the spring cruise and lower ingestion rates than expected from their relative contribution to the ambient nano- and microplankton in summer. Although clearance rates on them were lower than those on large cells (Table 2), during the summer $5 \mu \mathrm{m}$ flagellates contributed significantly to the diet (Fig. 4).

There were also clear differences between the feeding rates on larger cells (Table 2). Phaeocystis colonies were not ingested in spring at Stns C6M and C11M on the Greenland shelf (Fig. 4). Strombidium sp was actively selected at the Irminger Basin Stns B4M, B6M, B8M and B10M (Fig. 4). However, when the percentage of diatoms was higher (Stns I1M and B1M) they were cleared at higher rates than ciliates and other small cells. This was the case both in spring and summer, when diatom composition was dominated by Calanus pelagicus (Stns I1M and B1M) and Tropodineis sp. (Stns I3J and DD11J), respectively. In fact, selectivity on Strombidium sp. decreased with increasing percentage diatom concentration (Fig. 5a) and this was due to a decrease in the filtration rate on Strombidium sp. (Fig. 5b).

\section{DISCUSSION}

The maximum clearance rates on large cells measured here are similar to rates from other field (Turner et al. 2001) and laboratory (Paffenhöfer 1971) studies. When measurable, clearance rates on small cells were also similar to laboratory measurements (Rey et al. 2001, MeyerHarms et al. 2002). Apparently, Calanus finmarchicus nauplii feed comparatively inefficiently on small cells and clearance rates increase with cell size (Fernandez 1979, Rey et al. 2001, Meyer-Harms et al. 2002).

The inefficient feeding on small cells effectively explains why the recruitment of Calanus finmarchicus nauplii to copepodites is linked with phytoplankton 
Table 2. Maximum naupliar filtration rates on different types of cells

\begin{tabular}{|lcc|}
\hline $\begin{array}{l}\text { Cruise } \\
\text { Species }\end{array}$ & $\begin{array}{c}\text { Maximum filtration rate } \\
\left(\mathrm{ml} \mathrm{ind}^{-1} \mathrm{~d}^{-1}\right)\end{array}$ & Stn \\
\hline Spring & & \\
$\quad$ Chaetoceros socialis & 20.3 & C6M \\
$\quad$ Guinardia striata $($ Rhizosolenia stolterfothii) & 15.3 & B6M \\
Thalassiosira sp. (cf. Th. gravida 25 $\mathrm{mm})$ & 12.6 & $\mathrm{C} 11 \mathrm{M}$ \\
Gyrodinium sp. (cf. G. britannicum) & 11.7 & I1M \\
Strombidium sp. $(>30 \mu \mathrm{m})$ & 11.7 & B1M \\
Mesodinium sp. $(>30 \mu \mathrm{m})$ & 10.1 & B10M \\
Chaetoceros pelagicus & 10.0 & I1M \\
Strombidium sp. $(20-30 \mu \mathrm{m})$ & 7.6 & B6 \\
Summer & & \\
Cocolithophorids & 27.1 & B1J \\
Nanoneis haslea & 14.4 & B5J \\
Tropidoneis sp. & 13.4 & C8J \\
Gyrodinium sp. (cf. G. fusiformis) & 12.0 & C8J \\
Flagellates $5 \mu \mathrm{m}$ & 4.2 & DD11J \\
Flagellates $2 \mu \mathrm{m}$ & 1.8 & DD11J \\
\hline
\end{tabular}

ford \& Caron 2000). However, in the North Atlantic oceanic waters, ciliates rarely reach concentrations comparable to those of phytoplankton blooms (Gifford et al. 1995, Irigoien et al. 1998), and it is therefore unlikely that ciliates can sustain the cohort's recruitment from nauplii to copepodite. It is probable that the increase in ciliate biomass in the North Atlantic oceanic waters follows the phytoplankton bloom because the latter is the major input of organic matter into the system (Irigoien et al. 1998).

Calanus finmarchicus seemingly ingests non-motile diatoms over motile ciliates, contrary to what has been proposed to be the adult behaviour (e.g. Nejstgaard et al. 2001). Different phytoplankton may have different

blooms. Small flagellates suffer heavy predation from other microzooplankton (Gifford et al. 1995) and do not usually reach sufficient concentrations to effectively sustain a Calanus nauplius with a clearance rate of $<5 \mathrm{ml}$ ind. $^{-1} \mathrm{~d}^{-1}$ (Table 2). When the concentration of larger cells increases at the onset of the bloom, the higher filtration rates on diatoms (>10 ml ind..$\left.^{-1} \mathrm{~d}^{-1}\right)$ may result in a disproportionate increase in ingestion rates. Campbell et al. (2001) found that a $70 \mathrm{mg} \mathrm{C} \mathrm{m}^{-3}$ concentration was necessary for $C$. finmarchicus nauplii to achieve maximum growth rates. The differences in feeding efficiency we found indicate that whether maximum growth rates are attained in the field depends both on concentration and composition of the phytoplankton. This might also explain why during the summer in the North Atlantic, when phytoplankton biomass is still relatively high $\left(\sim 1 \mathrm{mg} \mathrm{chl} \mathrm{a} \mathrm{m}^{-3}\right)$ but dominated by small flagellates, there is no recruitment of additional cohorts of $C$. finmarchicus (Heath et al. 2000).

Calanus finmarchicus nauplii also clear ciliates at high rates, and ciliates make a significant contribution to the diet in areas with low phytoplankton biomass (Fig. 4). It has to be taken into account that in the present study, we did not correct for possible losses or shrinkage of ciliates, so their contribution to the diet is probably higher (Gif-
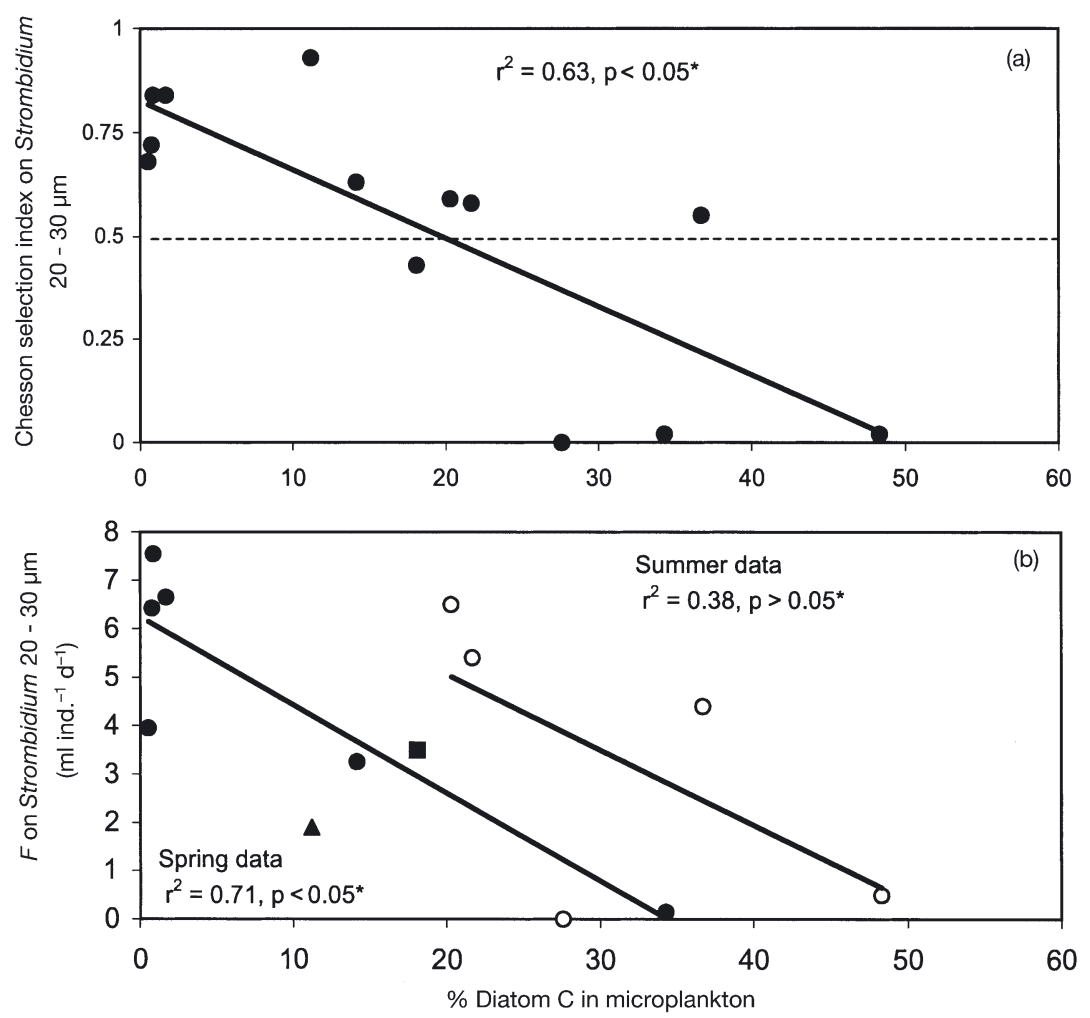

Fig. 5. (a) Chesson's selection index on Strombidium sp. (20 to $30 \mu \mathrm{m})$ vs percentage of diatoms in the microplankton. *Untransformed data presented but $\mathrm{r}^{2}$ and p calculated after arcsine transformation of the data. (b) Filtration rates (F) on Strombidium sp. (20 to $30 \mu \mathrm{m})$ vs percentage of diatoms in the microplankton. Symbols as in Fig. 3. * Untransformed data presented but $\mathrm{r}^{2}$ and $\mathrm{p}$ calculated after arcsine transformation of the data 
of different quality (Fernandez 1979); however, a simpler explanation is also available. Many ciliates (and dinoflagellates) are able to detect fluid disturbances generated by moving or filtering predators, and respond to feeding currents by vigorous escape jumps (Jakobsen 2001, 2002). Consequently, the capture efficiency would be lower for ciliates than diatoms. When also considering the potentially long handling time for large chain-forming or pennate diatoms, the lower clearance rates on ciliates when diatoms are abundant are not surprising. Both the apparent preference for non-motile diatoms in our experiments, and the feeding rates, generally agree with the behavioural observations and model predictions of Titelman \& Kiørboe (2003). Late naupliar stages of Calanus swim with a more or less continuous cruising motion, which allows for sufficient encounters with non-motile food, such as diatoms (Titelman \& Kiørboe 2003). In contrast, nauplii with a jump-sink behaviour rely on prey motility for food encounter (Titelman \& Kiørboe 2003).

The concept that adult Calanus finmarchicus prefer ciliates to phytoplankton also needs to be viewed with caution. For example, Irigoien et al. (1998) concluded that clearance rates of adult $C$. finmarchicus on ciliates are higher than on phytoplankton, but their observations related ingestion to total phytoplankton with a high percentage of small cells. When relating ingestion to chl $a>5 \mu \mathrm{m}$, clearance rates on phytoplankton were at least as high as those on ciliates. It is also important to distinguish between pre- or post-bloom and bloom periods when diatoms dominate. Often cited as examples of Calanus preferring ciliates, Fessenden \& Cowles (1994) and Levinsen et al. (2000) actually showed that ciliates are important before or after the bloom, but when the diatom bloom develops their contribution to diet becomes negligible. This may suggest a general sequence of food preference for Calanus; diatoms $>$ ciliates $>$ small phytoplankton. However, our data (Table 2) indicates that such a clear distinction between microplanktonic food categories does not really exist (e.g. high filtration rates on Gyrodinium britannicum).

Food preference depends on a host of prey characteristics (size, behaviour, form, palatability etc.), predator characteristics (behaviour, hunger, nutritional requirements etc.) and environmental varialbes (turbulence, temperature). It is not possible to include such complexity in models of the copepod population dynamics in the North Atlantic (e.g. Heath et al. 2000). Nevertheless, our results indicate that at least 2 factors should be regularly measured in the field and considered in models, if they are to correctly predict the recruitment of Calanus copepodites: the concentration of ciliates and the concentration of chl $a>5 \mu \mathrm{m}$.
Acknowledgements. This study was funded by the NERC Marine Productivity Thematic Programme (project NER/ T/S/2001/01256).

\section{LITERATURE CITED}

Båmstedt U, Gifford D, Atkinson A, Irigoien X, Roman M (2000) Zooplankton feeding. In: Harris RP, Wiebe P, Lenz J, Skjoldal HR, Huntley M (eds) ICES zooplankton methodology manual. Academic Press, London, p 297-399

Burkill PH, Edwards ES, John AWG, Sleigh MA (1993) Microzooplankton and their herbivorous activity in the northeastern Atlantic Ocean. Deep-Sea Res II 40:479-493

Campbell RG, Wagner MW, Teegarden GJ, Boudreau CA, Durbin EG (2001) Growth and development rates of the copepod Calanus finmarchicus reared in the laboratory. Mar Ecol Prog Ser 221:161-183

Chesson J (1978) Measuring preference in selective predation. Ecology 59:211-215

Fernandez F (1979) Particle selection in the nauplius of Calanus pacificus. J Plankton Res 4:313-328

Fessenden L, Cowles TJ (1994) Copepod predation on phagotrophic ciliates in Oregon coastal waters. Mar Ecol Prog Ser 107:103-111

Frost BW (1972) Effects of size and concentration of food particles on the feeding behavior of the marine planktonic copepod Calanus pacificus. Limnol Oceanogr 17:805-815

Gifford D, Caron, DA (2000) Sampling, preservation, enumeration and biomass of marine protozooplankton. In: Harris RP, Wiebe P, Lenz J, Skjoldal HR, Huntley M (eds) ICES zooplankton methodology manual. Academic Press, London, p 193-221

Gifford D, Fessenden LM, Garrahan PR, Martín E (1995) Grazing by microzooplankton and mesozooplankton in the high-latitude North Atlantic ocean: spring versus summer dynamics. J Geophys Res 100:6665-6675

Harris RP (1996) Feeding ecology of Calanus. Ophelia 44: 85-109

Heath MR, Astthorsson OS, Dunn J, Ellertsen B and 10 others (2000) Comparative analysis of Calanus finmarchicus demography at locations around the Northeast Atlantic. ICES J Mar Sci 57:1562-1580

Hirche HJ, Brey T, Niehoff B (2001) A high frequency time series at ocean weather ship Station M Norwegian Sea: population dynamics of Calanus finmarchicus. Mar Ecol Prog Ser 219:205-219

Holligan PM, Harbour DS (1977) The vertical distribution and succession of phytoplankton in the western English Channel in 1975 and 1976. J Mar Biol Assoc UK 57: 1075-1093

Huntley ME, Ciminello P, Lopez MDG (1987) Importance of food quality in determining development and survival of Calanus pacificus (Copepod: Calanoida). Mar Biol 95: 103-113

Irigoien X, Head RN, Klenke U, Meyer-Harms B, Harbour D, Niehoff B, Hirche HJ, Harris R (1998) A high frequency time series at weathership M, Norwegian Sea, during the 1997 spring bloom: feeding of adult female Calanus finmarchicus. Mar Ecol Prog Ser 172:127-137

Jakobsen HH (2001) Escape response of planktonic protists to fluid mechanical signals. Mar Ecol Prog Ser 214:67-78

Jakobsen HH (2002) Escape of protists in predator-generated feeding currents. Aquat Microb Ecol 26:271-281

Lessard EJ, Swift E (1986) Dinoflagellates from the North Atlantic classified as phototrophic or heterotrophic by epifluorescence microscopy. J Plankton Res 8:1209-1215 
Levinsen H, Turner JT, Nielsen TG, Hansen BW (2000) On the trophic coupling between protists and copepods in arctic marine ecosystems. Mar Ecol Prog Ser 204:65-77

Lopez MDG (1996) Effect of starvation on development and survivorship of nauplian Calanus pacificus (Brodsky). J Exp Mar Biol Ecol 203:133-146

Marshall SM, Orr AP (1956) On the biology of Calanus finmarchicus IX. Feeding and digestion in the young stages. J Mar Biol Assoc UK 35:587-603

Meyer-Harms B, Irigoien X, Graeve M, Head RN, Harris RP (2002) Feeding rates and selectivity among nauplii, copepodites and adult females of Calanus finmarchicus and Calanus helgolandicus. Helgol Mar Res 56:169-176

Nejstgaard JC, Naustvoll LJ, Sazhin A (2001) Correcting for underestimation of microzooplankton grazing in bottle incubation experiments with mesozooplankton. Mar Ecol Prog Ser 221:59-75

Niehoff B, Klenke U, Hirche HJ, Irigoien X, Head RN, Harris RP (1999) A high frequency time series at Weathership M, Norwegian Sea, during the 1997 spring bloom: the reproductive biology of Calanus finmarchicus. Mar Ecol Prog Ser 176:81-92

Ohman MD, Hirche HJ (2001) Density dependent mortality in an oceanic copepod population. Nature 412:638-641

Ohman MD, Runge JA (1994) Sustained fecundity when

Editorial responsibility: Thomas Kiørbe (Contributing Editor), Charlottenlund, Denmark phytoplankton resources are in short supply: omnivory by Calanus finmarchicus in the Gulf of St Lawrence. Limnol Oceanogr 39:21-36

Paffenhofer GA (1971) Grazing and ingestion rates of nauplii, copepodids and adults of the marine planktonic copepod Calanus helgolandicus. Mar Biol 286-298

Planque B, Batten S (2000) Calanus finmarchicus in the North Atlantic: the year of Calanus in the context of interdecadal change. ICES J Mar Sci 57:1528-1535

Rey C, Harris RP, Irigoien X, Head RN, Carlotti F (2001) Influence of algal diet on growth and ingestion of Calanus helgolandicus. Mar Ecol Prog Ser 216:151-165

Strathmann RR (1967) Estimating the organic carbon content of phytoplankton from cell volume or plasma volume. Limnol Oceanogr 12:411-418

Titelman J, Kiørboe T (2003) Motility of copepod nauplii and implications for food encounter. Mar Ecol Prog Ser 247: 123-135

Turner JT, Levinsen H, Nielsen TG, Hansen BW (2001) Zooplankton feeding ecology: grazing on phytoplankton and predation on protozoans by copepod and barnacle nauplii in Disko Bay, West Greenland. Mar Ecol Prog Ser 221:209-219

Utermöhl H (1958) Zur Vervollkommnung der quantitativen Phytoplankton Methodik. Mitt Int Ver Theor Angew Limnol 9:1-38

Submitted: March 26, 2003; Accepted: August 15, 2003 Proofs received from author(s): October 23, 2003 